\title{
Internalisasi Nilai-Nilai Aswaja Pada Organisasi Gerakan Pemuda Ansor Di Kota Padang
}

\author{
Husnul Habib Sihombing ${ }^{1}$, Erianjoni Erianjoni ${ }^{2}$ \\ 1,2Univesitas Negeri Padang \\ email: habibsihombing21@gmail.com
}

\begin{abstract}
Abstrak
Tujuan dari penelitian ini untuk menjelaskan internalisasi penanaman nilai-nilai Ahlussunnah waljama'ah pada kegiatan-kegiatan dan pergerakan Organisasi Gerakan Pemuda Ansor di Kota Padang. Penelitian ini dianalisis dengan mengunakan teori Peter L Berger tentang konstruksi realitas atau konstruksi kenyataan sosial. Penelitian ini menggunakan pendekatan kualitatif dengan tipe penelitian studi kasus intrinsik. Pemilihan informan dilakukan secara purposive sampling dengan jumlah informan 20 orang yang terdiri dari pengurus dan keanggotaan organisasi Gerakan Pemuda Ansor di kota Padang. pengumpulan data dilakukan dengan observasi aktif, wawancara mendalam dan studi dokumentasi. Untuk mendapatkan keabsahan dilakukan triangulasi yaitu triangulasi sumber dan triangulasi teknik. Data yang diperoleh dianalisis dengan menggunakan model analisis Miles dan Huberman (reduksi data, penyajian data, dan penarikan kesimpulan). Temuan dalam penelitian ini adalah terdapat empat nilai-nilai ASWAJA yang dimiliki oleh organisasi Gerakan Pemuda Ansor yaitu (1) Nilai Tawassuth (2) nilai Tawazun (3) Nilai Tasamuh (4) Nilai I'tidal. Penerapan nilai-nilai ASWAJA pada organisasi Gerakan Pemuda Ansor di Kota Padang dengan melakukan (a) Pelatihan Kepemimpinan Dasar (b) melakukan kegiatan majelis zikir dan shalawatan (c) kegiatan peduli umat (d) diskusi kerukunan umat.
\end{abstract}

Kata kunci : Internalisasi, Nilai-nilai ASWAJA, Organisasi

\begin{abstract}
Abstact
The purpose of this study is to explain the internalization of the cultivation of Ahlussunnah waljama'ah values on activities and movements of the youth movement in the city of Padang. this study was analyzed using Peter L Berger's theory of reality construction or social reality construction. This study uses a qualitative approach with the type of intrinsic case study research. The selection of informants was carried out by purposive sampling with a total of 20 informants consisting of administrators and members of the ansor youth movement organization in the city of Padang. data collection is done by active observation, in-depth interviews and documentation studies. To get the validity of triangulation, source triangulation and technical triangulation. The data obtained were analyzed using Miles and Huberman analiysis models (data reduction, data presentation and conclusion drawing). The findings in this study are that there are four ASWAJA values possessed by the organization of the youth movement namely (1) tawassuth value (2) tawazun value (3) tasamuh Value (4) I'itidal value. The application of ASWAJA values to the youth movement organization in the city of Padang by doing (a) basic leadership training (b) conduct activities of the meeting of dhikr and shalawatan (c) community care activities $(d)$ discussion of religious harmony.
\end{abstract}

Key Words: Internalization, ASWAJA Values, Organization 


\section{Pendahuluan}

Organisasi adalah bentuk formal dari sekelompok manusia dengan tujuan individualnya masing-masing gaji, kepuasan kerja, dan lain-lain yang bekerjasama dalam suatu proses tertentu untuk mencapai tujuan bersama yaitu tujuan organisasi. Organisasi Gerakan Pemuda Ansor diseluruh Indonesia yang berada pada pimpinan anak cabang masing-masing daerah memiliki visi dan misi yang sama dalam peranannya dibidang penanaman nilai-nilai ASWAJA. Pada organisasi ini banyak sekali manfaatnya dalam penanaman nilai-nilai ASWAJA yang telah diterapkan. Gerakan Pemuda Ansor sebagai salah satu organisasi sosial keagamaan mempunyai kiprah antara lain berpartisipasi aktif dalam melakukan dakwah tentang nilai-nilai ASWAJA yang merupakan pedoman dalam organisasi tersebut.

Organisasi Gerakan Pemuda Ansor (GPA) menganut faham Islam Ahlussunnah Wal Jama'ah yang tercantum dalam Peraturan Dasar Peraturan Rumah Tangga Peraturan Organisasi Gerakan Pemuda Ansor pada BAB II pasal 2 yaitu, "Gerakan Pemuda Ansor beraqidah Islam Ahlussunnah Waljama'ah yang dalam bidang akidah mengikuti madzhab Imam Abu Hasan AlAsy'ari dan Imam Abu Mansyur Al-Maturidi dalam bidang fiqih mengikuti salah satu dari Madzhab Empat ( Hanafi, Maliki, Syafi'I dan Hambali) dan dalam bidang tasawuf mengikuti madzhab Imam Al-Junaidi Al-Bagdadi dan Abu Hamid Al-Ghazali”. ${ }^{1}$

Organisasi Gerakan Pemuda Ansor diseluruh Indonesia yang berada pada pimpinan anak cabang masing-masing daerah memiliki visi dan misi yang sama dalam peranannya dibidang penanaman nilai-nilai ASWAJA. Pada oranisasi ini banyak sekali manfaatnya dalam penanaman nilai-nilai ASWAJA yang telah diterapkan, gerakan Pemuda Ansor sebagai salah satu organisasi sosial keagamaan mempunyai kiprah antara lain berpartisipasi aktif dalam melakukan dakwah tentang nilai-nilai ASWAJA yang merupakan pedoman dalam organisasi tersebut. ${ }^{2}$

Keberadaan GP Ansor di Kota Padang memiliki dua bentuk pergerakan, yaitu dari luar dan dalam. Pergerakan dari luar yaitu pergerakan yang dilakukan dengan melakukan sosialisai tentang nilai-nilai ASWAJA ${ }^{3}$ dengan melakukan acara zikir, shalawatan, dan kajian-kajian islam di lingkungan masyarakat dan di mesjid-mesjid dengan khas Nahdlatul Ulama. Pergerakan dari dalam yaitu mereka melakukan Pelatihan Kader Dasar (PKD) untuk penanaman nilai-nilai islam dan paham tentang kepemipinan yang diwarnai dengan khas ASWAJA. PKD sendiri dilakukan antara 3-4 kali dalam setahun untuk penambahan kader/anggota. Organisasi GP Ansor sendiri berjalan dengan tidak terlalu terbuka karna memiliki alasan bahwa Ansor punya pergerakan lain yang mampu berkembang tanpa harus melakukan aksi dan berkoar-koar di kalangan masyarakat, cukup dengan melakukan kajian islam dan sosialisasi dari satu tempat ketempat lain dengan paham ASWAJA dan berjalan pasti.

Dari hasil wawancara sementara peneliti dengan bapak ketua Organisasi GP Ansor Kota Padang bahwasanya kengggotaan dalam organisasi Ansor sebagian bukan berlatar belakang dari aliran ASWAJA atau NU, namun ada beberapa dari mereka yang berasal dari organisasiorganisasi Islam lain seperti Muhammadiyah, Jama'ah tabligh dan masyarakat umum serta dari kader partai politik yang juga berminat untuk masuk bergabung dalam organisasi gerakan pemuda Ansor untuk mempelajari nilai-nilai Agama yang dilandasi dengan paham ASWAJA.

\footnotetext{
${ }^{1}$ Peraturan Dasar Peraturan Rumah Tangga Peraturan Organisasi Gerakan Pemuda Ansor. 2016 Jakarta: Sekretariatan Jendral Pimpinan Pusat Gerakan Pemuda Ansor.

${ }^{2}$ Suaedy, Dkk. 2000. Akhlak-Akhlak Islam. Yogyakarta: Gaja Mada University Press.
} 
Penelitian ini dianalisis dengan mengunakan teori Peter L Berger tentang konstruksi realitas atau konstruksi kenyataan sosial. Berger berpandangan bahwa kenyataan itu dibangun secara sosial dalam pengertian individu-individu dalam masyarakat yang telah membangun masyarakat. Maka pengalaman individu tidak dapat terpisah dengan masyarakat. Manusia sebagai pencipta kenyataan sosial memulai momen diakletis (1) ekternalisasi yaitu bentuk ekspresi diri untuk menguatkan eksistensi individu dalam masyarakat seperti kegiatan-kegiatan yang dilakukan GP Ansor dilingkungan masyarakat, (2) objektivitas yaitu hasil yang telah dicapai GP Ansor dalam tujuannya, (3) internalisasi yang merupakan penyerapan kembali dunia objektif kedalam kesadaran sedemikian rupa sehingga objektif individu dipengaruhi oleh struktur dunia sosial.

\section{Metode Penelitian}

Penelitian ini dilakukan di rumah ketua GP Ansor Kota Padang, tepatnya dijalan Rumah Tigo Ruang, Kelurahan Anduring, kecamatan Kuranji, Kota Padang. Internalisasi nilai-nilai ASWAJA merupakan proses penanaman nilai-nilai yang berkaitan dengan paham Ahlussunnah waljama'ah. Dengan adanya keanggotaan yang bukan berlatar berlatar belakang dari paham Aswaja dan NU merupakan sebuah latar belakang penulis untuk melakukan penelitian ini. Penelitian ini dilakukan dengan pendekatan kualitatif, yang berusaha mengungkapkan realitas yang ada dilapangan. Teknik pengambilan informan yaitu dengan purposive sampling ${ }^{4}$. Penarikan informan penelitian dilakukan dengan sengaja dan peneliti menentukan sendiri kriteria informan penelitian yaitu orang yang terlibat dalam oranisasi GP Ansor di Kota Padang. Adapun kriteria informan adalah orang yang terlibat dalam GP Ansor yaitu: ketua GP Ansor Sumatera Barat, sekretaris GP Ansor Sumatera Barat, serta ketua GP Ansor Kota Padang beserta jajarannya. Selain itu, informan juga diambil dari, anggota yang pernah di kader di GP Ansor. dalam hal ini bundo ketua GP Ansor Kota Padang yang menjadi informan kunci karena beliau yang lebih memahami tentang kondisi dan pergerakan GP Ansor di Kota Padang. Setelah melakukan penelitian informan berjumlah 20 orang.

Teknik pengumpulan data yang dilakukan penelitian ini adalah dengan menggunakan observasi, wawancara, dan studi dokumentasi. Jenis observasi dalam penelitian ini adalah observasi aktif, dimana peneliti terlibat langsung didalam objek penelitian. Observasi pasif, sewaktu pengumpulan data peneliti mengamati aktivitas informan dalam setiap kegiatan yang dilakukan oleh GP Ansor Kota Padang, serta mengamati lingkungan sekitar, kondisi tempat dan lingkungan yang sedang terjadi. Wawancara yang dilakukan peneliti adalah wawancara mendalam (Indept interview) dan wawancara bersifat bebas. Wawancara mendalam dilakukan kepada setiap informan yang dipilih dalam puposive sampling, pertanyaan yang diberikan kepada informan sesuai dengan pedoman wawancara yang telah disediakan. Dengan poin-poin wawancara. Poin- poin wawancara tersebut dikembangkan lagi dalam bentuk pertanyaanpertanyaan yang terkait dengan internalisasi nilai-nilai aswaja pada organisasi gerakan pemuda ansor di kota padang.

Untuk melengkapi data dokumentasi dilakukan dengan mengambil foto-foto, merekam suara, atau pun merekam video, catatan harian observasi dan catatan harian wawancara terkait dengan internalisasi nilai-nilai aswaja pada organisasi Gerakan Pemuda Ansor di Kota Padang.

${ }^{4}$ Burhan Bungin.2003.Data Penelitian Kualitatif. Jakarta. PT Rsaja Grafindo Persada. Hlm. 53 
Untuk menguji keabsahan data peneliti menggunakan teknik triangulasi data. Jenis triangulasi yang digunakan dalam penelitian ini yaitu triangulasi sumber.

\section{Hasil dan Pembahasan}

\section{Hasil}

Peneliti menemukan ada 4 proses internalisasi nilai-nilai Aswaja dalam organisasi GP Ansor Kota Padang yaitu (1). Pelatihan Kepemimpinan Dasar (PKD), yaitu sebuah kegiatan untuk penerimaan anggota baru sekaligus untuk meningkatkan kulitas dan potensi peserta PKD dengan memperkuat kapasitas, potensi, keterampilan dan profesionalitas dalam bidang-bidang tertentu sesuai dengan kebutuhan diri, organisasi dan masyarakat. Kegiatan ini menanamkan nilai-nilai Aswaja yang meliputi nilai pertama, Tawassuth/sifat ditengah-tengah atau tidak memihak, kedua nilai Tawazun yaitu menjaga keseimbangan dan keselarasan sehingga terpelihara secara seimbang antara kepentingan dunia dan akhirat, kepentingan pribadi danmasyarakat, dan kepentingan masa kini dan yang akan datang, ketiga nilai Tasamuh yaitu bersifat toleransi terhadap perbedaan pandangan, terutama dalam hal yang bersifat kepercayaan, sehingga tidak terjadi perasaan saling terganggu, saling memusuhi, dan sebaliknya akan tercipta persaudaraan yang Islamiah ( $u k h u w w a h$ islamiyyah). Terakhir Nilai I'tidal yaitu sifat adil, tegak lurus atau menempatkan sesuatu pada tempatnya. Maksudnya menempatkan sesuatu pada tempatnya ialah mengajak pada kebenaran dan mencegah kepada hal yang mungkar dan ini merupakan alasan salah satu tujuan syari'at dalam bidang hukum (2). GP Ansor Padang juga melakukan kegiatan majelis Zikir dan Shalawatan, pelaksanaan kegiatan ini dilakukan atas dasar pembentukan dan penanaman nilai-nilai yang dilakukan untuk menjalin hubungan sesama manusia dalam beribadah. Hal ini Tujuan menanamkan nilai-nilai Asawaja melalui Ibadan dan membentuk generasi untuk mampu menjadi penerus serta dapat mengajarkan peribadahan yang dilakukan secara besama-sama atas dasar nilai-nilai Aswaja. (3). Kegiatan Peduli Umat, yaitu sebuah agenda yang merangkup beberapa kegiatan didalamnya, yang pertama Da'I Cyber, yaitu sebuah pergerakan GP Ansor yang bergerak didunia maya. Kedua pelatihan jurnalistik, yaitu pergerakan yang bertujuan untuk membentuk karakter dan pengenbangan wawasan anggota Ansor dalam bidang jurnalistik. Yang terakhir berbagi amal, sebuah kegiatan yang dilakukan atas dasar keumatan dan kepedulian sesama manusia. Kegiatan ini dilakukan ketika ada bencana alam yang melanda sebuah daerah. dalam kegiatan peduli umat tersebut menerapkan dan menanakan dasar nilai-nilai Aswaja untuk membentuk kepribadian anggota dalam setiap kegiatan yang dilakukan GP Ansor di Kota Padang. (4). Diskusi Kerukunan Umat, yaitu sebuah penanaman nilai aswaja yang memperkenalkan anggota dengan paham/ideologi lain dalam berdiskusi untuk menetralisir segala hal yang dapat menghalang atau mengancam kerukunan umat beragama.

\section{Pembahasan}

Menurut Kartono, internalisasi adalah pengaturan kedalam fikiran atau kepribadian, pembuatan nilai-nilai, patokan-patokan ide atau praktek-praktek dari orang lain atau organisasi yang menjadi sebagai bagian dari diri seseorang. Internalisasi secara etimologi dalam kaidah bahasa Indonesia kata yang berakhiran "isasi" mempunyai defenisi sebuah proses, sehingga internalisasi dapat diartikan sebagai sebuah proses. Internalisasi menunjukkan bahwa suatu proses yang kita dapat sejak kita lahir sehingga kita memperoleh aturan-aturan melalui sebuah komunikasi, seperti adanya sosialisasi dalam kehidupan bermasyarakat. Internalisasi merupakan 
proses penyerapan nilai-nilai dan norma-norma, pola tingkah laku dan nilai-nilai kultur secara langsung atau tidak langsung guna beradaptasi dengan keadaan, kondisi dan lingkungan sosial

Internalisasi adalah proses memasukkan nilai-nilai atau memasukkan nilai ideal yang sebelumnya dianggap berada diluar, dan agar tergabung dalam pemikiran seseorang dalam pemikiran, keterampilan dan sikap pandangan hidup seseorang. Internalisasi juga dapat diartikan sebagai pengumpulan nilai-nilai tertentu agar tebentuk menjadi pribadi yang utuh.

Menurut Peter L Berger tentang Konstruksi Realitas atau konstruksi Kenyataan sosial bahwa dalam teori ini dapat dilihat pergerakan Organisasi GP Ansor merupakan suatu proses sosial yang dilakukan dengan adanya interaksi melalui penyampaian materi pada pelaksanaan kegiatan-kegiatan GP Ansor di Kota Padang dan dimana tiap-tiap kader melakukan tindakan yang memiliki tujuan yang sama secara bersama-sama yaitu penanaman nilai-nilai Aswaja yang ditanamkan dari kegiatan yang dilakukan terhadap peserta yang akan menjadi Anggota GP Ansor.

\section{Kesimpulan}

Jika dianalisis dengan teori Peter L Berger tentang konstruksi realitas menekankan bahwa semua pengetahuan kita mengenai fakta objektif dalam dunia kenyataan ditentukan atau diwarnai oleh lingkungan sosial dimana pengetahuan itu diperoleh atau dipelajari. Maka dari hasil penelitian telah dijelaskan bahwa penanaman nilai-nilai aswaja yang dilakukan organisasi GP Ansor adalah melalui pendekatan dengan kegiatan-kegiatan yang berbaur dengan masyarakat. penelitian ini bertujuan untuk menjelaskan tentang internalisasi nilai-nilai Ahlussunnah Waljama'ah pada Organisasi Gerakan Pemuda Ansor di Kota Padang.

Organisasi GP Ansor Kota Padang berupaya menciptakan anggota kader Ansor mampu memiliki, memahami dan menanamkan Nilai-nilai Aswaja yang merupakan ideologi organisasi Ansor yang dan badan otonom dari NU untuk menjadikan nilai-nilai tersebut sebagai karakter dan akhlak kepemudaan yang mampu menjadi panutan serta memberikan perubahan dalam kepemimpinan dan kemajuan bangsa yang telah dibentuk dalam segala kegiatan yang dilakukan dalam organisasi Ansor.

\section{Daftar pustaka}

Burhan Bungin.(2003). Data Penelitian Kualitatif. Jakarta: PT Raja Grafindo Persada.

Sekretariatan Jendral Pimpinan Pusat Gerakan Pemuda Ansor .(2016) Peraturan Dasar Peraturan Rumah Tangga Peraturan Organisasi Gerakan Pemuda Ansor. Jakarta: Sekretariatan Jendral Pimpinan Pusat Gerakan Pemuda Ansor.

Suaedy, dkk. (2000). Akhlak-Akhlak Islam. Yogyakarta: Gaja Mada University Press.

Sugiyono. (2005). Memahami Penelitian Kualitatif. Jakarta: Alfabeta 